\title{
Rekomendasi Jurusan dengan Menggunakan Decision Tree pada Sistem Penerimaan Peserta Didik Baru SMK Widya Dharma Turen
}

\author{
Lazuardi Noorca Rachmadi, Aji Prasetya Wibawa, Utomo Pujianto \\ Universitas Negeri Malang
}

\begin{tabular}{|c|c|}
\hline INFO ARTIKEL & ABSTRAK \\
\hline $\begin{array}{l}\text { Riwayat Artikel: } \\
\text { Diterima: 01-02-2021 } \\
\text { Disetujui: 25-02-2021 }\end{array}$ & $\begin{array}{l}\text { Abstract: Each year the school selects prospective students who are selected } \\
\text { according to the criteria determined by the school. In general, the process of } \\
\text { admitting new students (PPDB) is carried out through the registration, } \\
\text { selection test and announcement stages. The decision tree is used to help } \\
\text { schools in the process of admitting new students to determine majors at the }\end{array}$ \\
\hline $\begin{array}{l}\text { Kata kunci: } \\
\text { PPDB } \\
\text { Decision tree } \\
\text { Waterfall method } \\
\text { Rekomendasi jurusan }\end{array}$ & $\begin{array}{l}\text { performance of the decision tree algorithm to get accurate results. With that, an } \\
\text { information system was created that would help schools to process new student } \\
\text { admissions accompanied by a decision support system for the selection of } \\
\text { majors. Based on the results, it can be concluded that the decision tree } \\
\text { algorithm supported by the waterfall development method will produce an } \\
\text { online-based new Student Admission Process (PPDB) system which will reduce } \\
\text { school performance to get prospective students who are in accordance with } \\
\text { school criteria.. }\end{array}$ \\
\hline & $\begin{array}{l}\text { Abstrak: Pada setiap tahunnya sekolah menyeleksi calon peserta didik yang } \\
\text { terpilih sesuai dengan kriteria yang ditentukan oleh sekolah. Pada umumnya } \\
\text { proses penerimaan peserta didik baru (PPDB) dilakukan melalui tahapan } \\
\text { pendaftaran, tes seleksi dan pengumuman. Decision tree digunakan untuk } \\
\text { membantu sekolah pada proses penerimaan peserta didik baru untuk } \\
\text { menentukan jurusan pada jenjang sekolah SMK. Mengunakan metode } \\
\text { Waterfall yang akan mendukung kinerja dari algoritma decision tree untuk } \\
\text { mendapatkan hasil yang akurat. Dengan itu, maka dibuatlah sebuah system } \\
\text { informasi yang akan membantu sekolah untuk melakukan proses penerimaan } \\
\text { peserta didik baru disertai dengan system pendukung keputusan untuk } \\
\text { pemilihan jurusan. Berdasarkan hasil dapat disimpulkan bahwa algoritma } \\
\text { decision tree dengan didukung metode pengembangan waterfall akan } \\
\text { menghasilkan system Proses Penerimaan Peserta Didik baru (PPDB) berbasis } \\
\text { online yang akan mengurangi kinerja sekolah untuk mendapatkan calon siswa } \\
\text { yang memang sesuai dengan kriteria sekolah. }\end{array}$ \\
\hline
\end{tabular}

\section{Alamat Korespondensi:}

Lazuardi Noorca Rachmadi,

Pendidikan Teknik Informatika

Fakultas Teknik

Universitas Negeri Malang

Jl. Semarang No.5, Sumbersari, Kec. Lowokwaru, Kota Malang, Jawa Timur 65145

E-mail: lazuardinoorca@gmail.com 


\section{PENDAHULUAN}

Pengertian sistem pengambil keputusan menurut (Azmi \& Dahria, 2013) proses pengambilan keputusan dibantu menggunakan computer untuk membantu pengambil keputusan dengan menggunakan beberapa data dan model tertentu untuk menyelesaikan beberapa masalah yang tidak terstruktur. Sistem hanya menghasilkan keluaran yang mengkalkulasi data-data sebagaimana pertimbangan seorang pengambil keputusan. Sehingga kerja pengambil keputusan dalam mempertimbangkan keputusan dapat dimudahkan. Selama ini pada pihak siswa menemui banyak kendala dengan belum adanya rekomendasi pemilihan jurusan yang membuat kurang tepatnya keinginan dan bakat siswa dalam memilih jurusan mana yang akan dituju . kendala tersebut ialah (1) siswa masih bingung manakah jurusan yang tepat dengan kemampuan berpikir mereka (2) siswa memiliki rasa takut tidak memahami mata pelajaraan yang diajarkan di jurusan yang telah mereka pilih (3) siswa merasa tidak memiliki kemampuan apapun diantara jurusan yang disediakan sekolah (Kusuma, 2015).

Masalah yang terjadi dengan tidak tepatnya siswa yang salah memilih jurusan di SMK adalah tidak tercapainya suatu nilai maksimal yang harusnya bisa dicapai siswa tersebut. Hal lain yang akan terjadi adalah kurang tertariknya para siswa untuk mempelajari suatu informasi baru yang diajarkan di jurusan tersebut ini mengakibatkan terjadinya proses pembelajaran yang setengah - setengah (Hasanah et al., 2018; Sulystiyawati \& Purwaningsih, 2014). Dalam bidang pendidikan masih banyak yang menggunakan selembar kertas ataupun hanya sekedar menggunakan aplikasi microsoft exel untuk mengelola data peserta didik baru. Salah satunya adalah SMK Widya Dharma Turen. Hal ini menyebabkan kemungkinan masih banyaknya kekurangan data dan terjadinya kesalahan dalam perhitungan nilai tes. Oleh karena itu, sering terjadi kesalahan perhitungan dan lambat dalam pengolahan data calon peserta didik (Permana, 2015).

Menurut hasil wawancara dengan guru maupun murid, dihasilkan sebuah kondisi dimana siswa yang mengalami salah jurusan terlihat tidak terlalu aktif pada saat dilaksanakan proses pembelajaran, siswa akan mengerjakan sesuatu yang tidak berhubungan dengan jurusan tersebut dan juga tugas yang diberikan oleh guru tidak akan dikerjakan dengan sungguh sungguh bahkan kondisi terburuk adalah dia tidak mengerjakan tugas yang diberikan guru tersebut. Kondisi dimana proses pembelajaran akan berlangsung pasif terhadap siswa tersebut dan akan menyebabkan hasil akademik dari siswa tersebut tidak mencapai maksimal. Oleh Karena itu sebuah sistem yang dapat membantu sekolah maupun siswa untuk memilih jurusan mana yang akan dituju sesuai dengan kemampuan berpikirnya adalah sangat dibutuhkan dalam penelitian ini penentuan pengambil keputusan kenaikan kelas dilakukan dengan menggunakan "Decision Tree". Decision Tree digunakan karena menggunakan prinsip mengidentifikasi dan melihat hubungan antara factor factor yang mempengaruhi suatu masalah dan dapat mencari penyelesaian terbaik dengan memperhitungkan factor factor tersebut (Aradea et al., 2011; Azmi \& Dahria, 2013). Dalam beberapa tahun terakhir, metode Decision Tree banyak diaplikasikan oleh beberapa peneliti dalam kasus yang berbeda. (Rismayanti, 2018) menerapkan Decision Tree untuk pengambilan keputusan pemberian beasiswa, (Kabari \& Nwachukwu, 2013) menerapkan Decision Tree dalam menentukan jadwal kerja, (Sahu \& Khare, 2014) mengimplementasikan Decision Tree sebagai analisa rekam medis.

Berdasarkan permasalahan di atas, SMK Widya Dharma Turen memerlukan sistem pendukung keputusan pada sistem penerimaan peserta didik baru. Sistem pendukung keputusan tersebut digunakan untuk memonitoring keputusan pemilihan jurusan yang memiliki tujuan untuk mengurangi hilangnya data pendaftar dan juga mempermudah para panitia PPDB untuk mengelompokkan para peserta yang akan daftar di sekolah SMK Widya Dharma (Hermanto, 2012). Untuk menentukan keputusan rekomendasi pemilihan jurusan menggunakan metode Decision Tree. Penerapan metode Decision Tree diharapkan dapat membantu pihak sekolah dalam memproses penerimaan peserta didik baru secara efektif dan efisien. Langkah - langkah yang digunakan untuk menyelesaikan masalah adalah sebagai berikut:

\section{Penelitan dan Pengembangan}

Penelitian dan pengembangan adalah metode yang digunakan dalam penelitian untuk menghasilkan produk tertentu serta untuk menguji keefektifan dari produk tersebut. Produk aplikasi menggunakan metode Decision Tree sebagai Sistem Pendukung Keputusan (SPK) pemilihan jurusan pada SMK. 


\section{Model waterfall}

Metode Waterfall yang dikemukakan oleh (Bassil, 2012). Penjelasan mengenai metode Waterfall dapat dilihat pada Gambar 1.

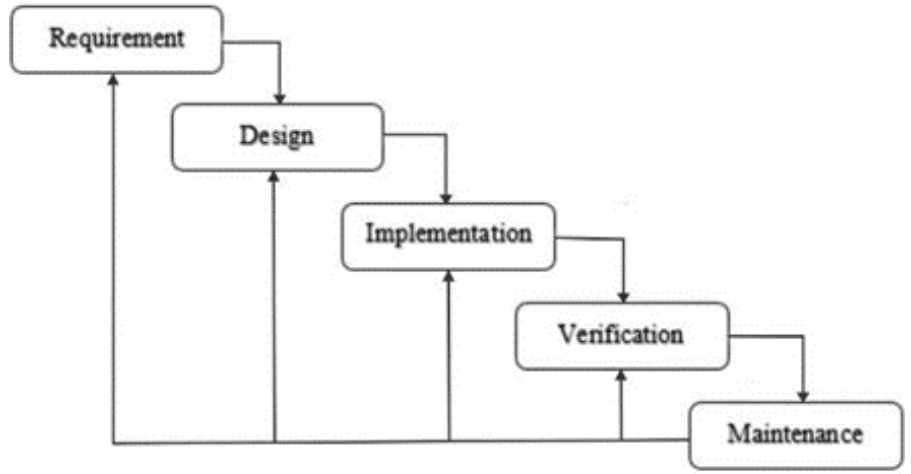

Gambar 1. Metode waterfall.

\section{Algoritma}

Tabel 1. Alhoritma Tabel

\begin{tabular}{|c|c|c|c|}
\hline No & Algoritma & Kelebihan & kekurangan \\
\hline 1. & K-Means & $\begin{array}{l}\text { Proses clustering data lebih mudah } \\
\text { digunakan }\end{array}$ & Inisialisai bersifat random \\
\hline 2 & Apriori & $\begin{array}{l}\text { Pemangkasa } \mathrm{n} \text { kandidat support yang } \\
\text { optimal }\end{array}$ & $\begin{array}{l}\text { Memerlukan waktu yang lama pada } \\
\text { proses scanning }\end{array}$ \\
\hline 3 & Naive bayes & Menangani kuantitatif data diskrit & $\begin{array}{l}\text { Jika probabilitas kondisinya adalah nol } \\
\text { maka prediksi akan } 0\end{array}$ \\
\hline 4 & $\begin{array}{l}\text { Expectation Maximisation } \\
\text { Algorithm }\end{array}$ & $\begin{array}{l}\text { Stabil secara numerik setiap iterrasi } \\
\text { naik }\end{array}$ & Algoritma EM bisa saja konvergen secara \\
\hline
\end{tabular}

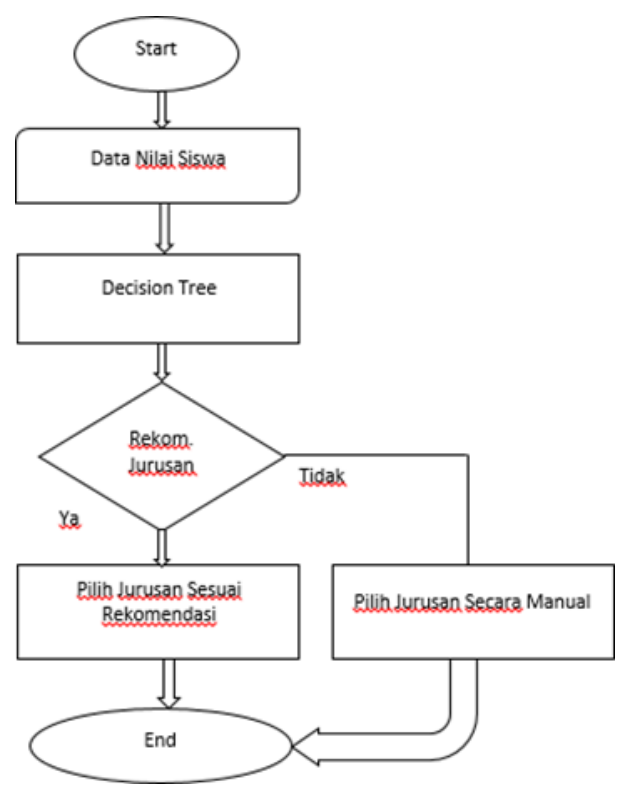

Gambar 2. Bagan metode yang digunakan 
Tabel 2. Data Kriteria

\begin{tabular}{ccc}
\hline No & Kode Kriteria & Keterangan \\
\hline 1 & K1 & Matematika \\
2 & K2 & IPA \\
3 & K3 & B. Inggris \\
4 & K4 & B. Indonesia \\
\hline
\end{tabular}

Tabel 3. Data Kategori

\begin{tabular}{ccc}
\hline No & Keterangan & Kategori \\
\hline 1 & Matematika & Bagus \\
2 & IPA & Kurang \\
3 & B. Inggris & Cukup \\
4 & B. Indonesia & Bagus \\
\hline
\end{tabular}

Setelah diperoleh data kriteria dan bobot masing-masing kriteria, selanjutnya akan dilakukan proses mendapatkanrekomendasi jurusan menggunakan Decision Tree.

\section{Decision Tree}

Teknik decision analysis yang peneliti pergunakan adalah Decision tree. Diperkenalkan pada tahun 1960-an oleh fredkin. Singkatnya yaitu Decision Tree merupakan metode yang khusus dalam proses pengklasifikasian pada Text Mining. (Han \& Kamber, 2006; Sambani \& Nuraeni, 2017) menyatakan yang disebut klasifikasi adalah proses penentuan kumpulan pola dan fungsi yang mendeskripsikan dan memisahkan data satu dengan kelas data lainnya, dan berguna untuk proses prediksi data yang belum memiliki kelas data tertentu. Gambaran umum dalam proses membangun pohon keputusan yang dilakukan algoritma $C 4.5$ adalah sebagai berikut:

1. Pilih salah satu atribut untuk sebagai akar.

2. Buat cabang untuk masing-masing nilai

3. Cabang yang telah dibagi akan diberikan kasus atau nilai tersendiri.

4. Ulangi proses untuk masing-masing cabang sampai semua kasus pada cabang memiliki kelas yang sama.

Atribut yang akan dipilih sebagai akar akan didapatkan berdasarkan dari nilai gain tertinggi diantara beberapa atribut yang digunakan. Rumus 1 akan menjelaskan bagaimana menghitung gain.

$$
\operatorname{Gain}(S, A)=\operatorname{Entropy}(S)-\sum_{i=l}^{n} \cdot \frac{S i}{S} * \operatorname{Entropy}(S i)
$$

Dengan:

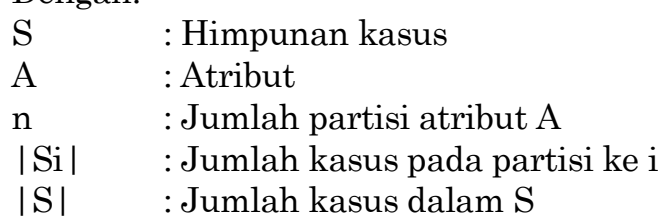

Beberapa tahapan algoritma C4.5, Larose dalam proses pembuatan pohon keputusan yaitu: 1) mempersiapkan data training. Data sudah dikelompokkan dalam kelas tertentu dan menggunakan Data training diambil dari data histori yang pernah terjadi sebelumnya, 2) hitung akar dari pohon. Nilai Akar berasal dari nilai gain atribut tertinggi dan akan menjadi akar pertama setelah menghitung nilai gain setiap atribut. Sebelum mendapatkan nilai gain dari suatu atribut, hitung dahulu nilai gain.

$$
\operatorname{Gain}(S, A)=\operatorname{Entropy}(S)-\sum_{i=l}^{n} \cdot \frac{S i}{S} * \operatorname{Entropy}(S i)
$$

Dengan :

S : Himpunan Kasus 


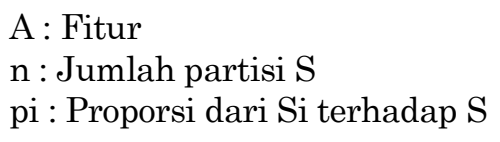

\section{Model Penelitian dan Pengembangan}

Metode Waterfall yang dikemukakan oleh (Bassil, 2012). Model ini memiliki lima tahapan (1). requierement , (2) Design , (3) Implementation , (4) Verification , (5) MaintenancePenjelasan mengenai metode Waterfall ada pada Gambar 3.

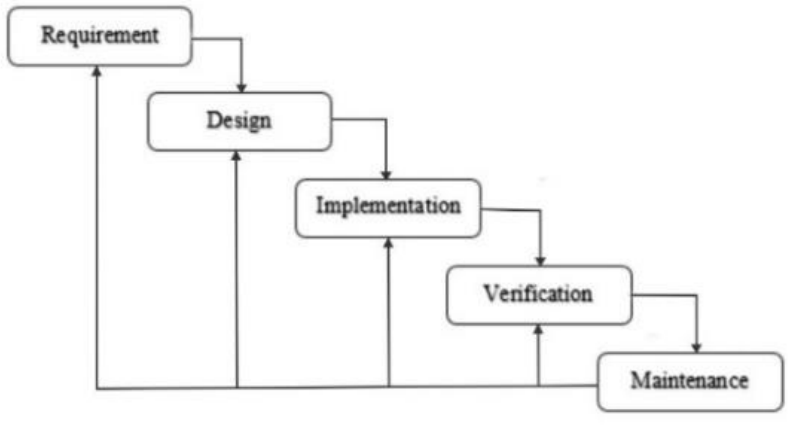

Gambar 3. Metode Waterfall

\section{Prosedur Penelitian dan Pengembangan}

Tahapan dari pengembangan yang digunakan sistem pendukung keputusan pembagian kelompok ini akan dipaparkan sebagai berikut:

\section{Requirement}

Requirement adalah tahap identifikasi masalah untuk ditetapkannya menu, permasalahan dan tujuan dibuatnya sistem setelah konsultasi dengan user sistem. Adapun permasalahan yang ditemui adalah: a) Sekolah memberikan formulir pendaftaran untuk calon peserta didik baru, b) calon peserta didik baru mengisi formulir dan mempertimbangkan jurusan mana yang akan dipilih, c) sekolah mengumpulkan Formulir pendaftaran secara manual, d) sekolah mengelompokkan formulir sesuai jurusan yang dipilih oleh calon peserta didik baru. Dari permasalahan tersebut, maka dikembangkan sistem pendukung keputusan untuk mengurangi permasalahan yang ada dengan menggunakan algoritma Decision Tree. Kebutuhan fungsionalitas pada sistem pendukung keputusan pembagian kelompok ditunjukkan di Tabel 4.

Tabel 4. Kebutuhan fungsionalitas pada sistem pendukung keputusan pembagian kelompok.

\begin{tabular}{ccc}
\hline No & Pengguna & Hak Akses \\
\hline 1 & Admin & Mengelola data pengguna \\
2 & Siswa & Mengisi nilai \\
& & Melihat nilai \\
& & Melihat hasil \\
\hline
\end{tabular}

\section{Design}

Setelah melakukan tahap requirements, tahapan selanjutnya yaitu software design dan system. Tahapan software design dan system memberikan gambaran analisis kebutuhan dalam bentuk blueprint. Blueprint yang dibuat di perancangan ini adalah sebagai berikut: a) diagram alur, b) data flow diagram, c) entity relationship data, dan d) penerapan metode Decision Tree. 


\section{Implementation}

Pada tahapan ini dilakukan penerjemahan design melalui pengkodingan atau dilakukan pembangunan sistem dalam satu program utuh. Setelah tahap pengkodingan, testing sistem adalah langkah selanjutnya agar dilakukan perbaikan pada kesalahan-kesalahan yang ada.

\section{Verification}

Pada tahap ini merupakan bisa dikatakan tahapan akhir proses pembentukan sistem. Selanjutnya sistem dilakukan pengujian oleh user untuk memeriksa kelayakan sistem. Pengujian sistem akan

\section{Maintenance}

Tahap ini dilakukan pemeliharaan pada sistem dikarenakan sistem memiliki sifat dinamis, data yang termuat didalam sistem bisa sewaktu-waktu mengalami perubahan tergantung kebutuhan. Kesalahan juga bisa muncul pada proses pengimplementasian sistem dan harus menyesuaikan dengan periperan dan diharuskan melakukan perkembangan sistem secara fungsional..

\section{HASIL DAN PEMIBAHASAN}

Pemodelan ini menjelaskan mengenai bagaimana tahapan dalam penerapan metode Decision Tree untuk menentukan rekomendasi jurusan calon siswa baru. Berikut penjelasan mengenai penggunaan metode Decision Tree dalam menentukan rekomendasi jurusan. Tahap awal dalam algoritma ini yaitu konversi data agar data yang digunakan dapat diolah. Pada konversi data, data yang sebelumnya bertipe nilai $0-100$ diubah menjadi Bagus, cukup, kurang sesuai dengan kriteria yang telah ditentukan dapat dilihat pada Tabel 5. Data awal siswa berisi nilai raport para calon peserta didik baru yang masih berupa numeric. Nilai konversi dan hasil siswa disajikan pada Tabel 6 dan 7.

\begin{tabular}{ccccc}
\multicolumn{2}{c}{ Tabel 5. Data Awal Siswa } \\
\hline Nama & C1 & C2 & C3 & C4 \\
\hline Siswa 1 & 100 & 94 & 77 & 55 \\
Siswa 2 & 90 & 87 & 54 & 89 \\
Siswa 3 & 87 & 65 & 77 & 45 \\
Siswa 4 & 81 & 87 & 89 & 86 \\
Siswa 5 & 76 & 86 & 41 & 55 \\
\hline
\end{tabular}

Tabel 6. Nilai Konversi Siswa

\begin{tabular}{ccccc}
\hline Nama & C1 & C2 & C3 & C4 \\
\hline Siswa 1 & Bagus & Bagus & Cukup & Rendah \\
Siswa 2 & Bagus & Bagus & Rendah & Bagus \\
Siswa 3 & Bagus & Cukup & Cukup & Rendah \\
Siswa 4 & Cukup & Bagus & Bagus & Bagus \\
Siswa 5 & Cukup & Bagus & Rendah & Rendah \\
\hline
\end{tabular}

Tabel 7. Data hasil konversi data nilai siswa sesuai krtiertia Dari SPK Rekomendasi jurusan.

\begin{tabular}{|c|c|c|c|c|c|c|c|}
\hline Mata Pelajaran & Kategori & Jumlah & Tkj & Apk & $\mathbf{A k}$ & Entrophy & Information Gain \\
\hline & & 50 & 4 & 6 & 5 & 0.990768547 & \multirow{3}{*}{0.783477988} \\
\hline \multirow[t]{2}{*}{ Matematika } & & & & & & & \\
\hline & Bagus & 6 & 2 & 1 & 3 & 1.459147917 & \\
\hline & Cukup & 5 & 1 & 2 & 2 & 1.521928095 & \multirow{5}{*}{0.558575738} \\
\hline \multirow{5}{*}{ Ipa } & Kurang & 4 & 1 & 2 & 1 & 1.5 & \\
\hline & & & & & & & \\
\hline & Bagus & 6 & 2 & 1 & 3 & 1.459147917 & \\
\hline & Cukup & 4 & 1 & 1 & 2 & 1.5 & \\
\hline & Kurang & 5 & 1 & 3 & 1 & 1.370950594 & \multirow{3}{*}{0.525084297} \\
\hline \multirow[t]{2}{*}{ Big } & & & & & & & \\
\hline & Bagus & 3 & 1 & 1 & 1 & 1.584962501 & \\
\hline
\end{tabular}




\begin{tabular}{cccccccc}
\hline Mata Pelajaran & Kategori & Jumlah & Tkj & Apk & Ak & Entrophy & Information Gain \\
\hline \multirow{4}{*}{ BIN } & Cukup & 9 & 2 & 4 & 3 & 1.530493057 & \\
& Kurang & 3 & 1 & 1 & 1 & 1.584962501 & BIN \\
& & & & & & 0.583477988 & \\
& Bagus & 6 & 1 & 4 & 1 & 1.251629167 & 1.5 \\
& Cukup & 4 & 2 & 1 & 1 & 1.370950594 & \\
& Kurang & 5 & 1 & 1 & 3 &
\end{tabular}

Setelah didapatkan hasil dari konversi nilai menjadi decision tree, didapatkan bahwa matematika mendapatkan gain tertinggi dan menjadi root dari pohon keputusan untuk turunan kebawahnya. Selanjutnya dilakukan pengujian menggunakan pendekatan Technology Acceptance Model (TAM) bertujuan untuk menjelaskan dan penerimaan suatu sistem informasi (Dewi et al., 2018) dengan menggunakan 50 responden yakni caloon siswa baru dan siswa kelas XI. Hasil pengujian Technology Acceptance Model (TAM) disajikan dengan visualisai grafik pada Gambar 4. Technology Acceptance Model (TAM)

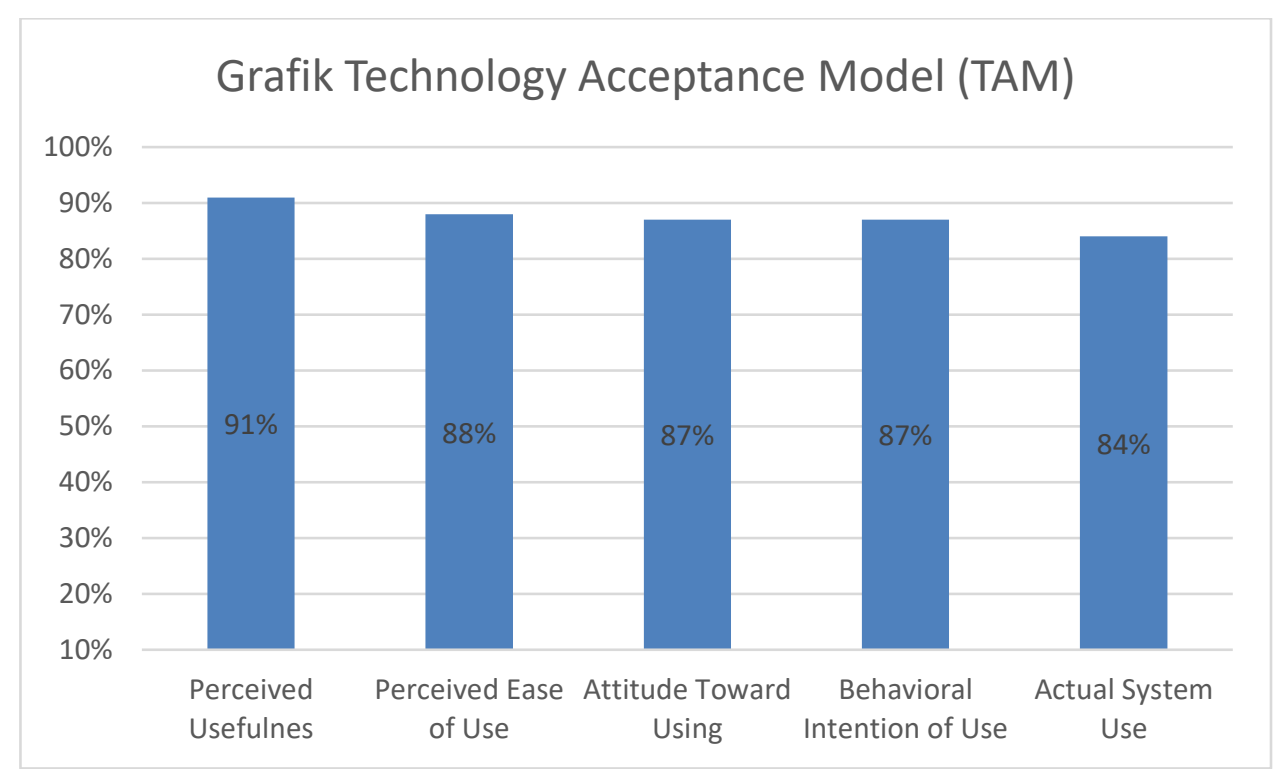

Gambar 4. Hasil pengujian Technology Acceptance Model (TAM)

Berdasarkan tahap pengujian pendekatan Technology Acceptance Model (TAM) mendapatkan rata-rata persentase sebesar 88\% sehingga sistem dikategorikan layak (Sugiyono, 2010), dapat disimpulkan bahwa sistem dengan menggunakan metode Decision Tree dapat digunakan pada proses rekomendasi jurusan pada proses penerimaan peserta didik baru SMK Widya Dharma Turen.

\section{SIMIPULAN}

Dari hasil penelitian yang telah dilakukan dapat ditarik kesimpulan bahwa hasil penelitian dari pengembangan sistem PPDB pada SMK Widya Dharma Turen dinyatakan siap dan layak diimplementasikan. Pengujian tingkat kelayakan menggunakan penguji Model Penerimaan Teknologi diperoleh rata - rata proporsi 88\% sehingga sistem rekomendasi menggunakan pohon keputusan dapat membantu proses penerimaan peserta didik baru pada SMK Widya Dharma Turen.

\section{DAFTAR RUJUKAN}

Aradea, S. A., Ariyan, Z., \& Yuliana, A. (2011). Penerapan Decision Tree untuk penentuan pola data penerimaan mahasiswa baru. Jurnal Penelitian Sitrotika, 7(1), 1693-9670.

Azmi, Z., \& Dahria, M. (2013). Decision tree berbasis algoritma untuk pengambilan keputusan. Jurnal Ilmiah Saintikom, 12(3), 157-164. 
Bassil, Y. (2012). A simulation model for the waterfall software development life cycle. In arXiv preprint arXiv:1205.6904.

Dewi, N. L. C., Wibawa, A. P., \& Pujianto, U. (2018). Technology Acceptance Model on Internship Placement Recommendation System based on Naïve Bayesa. 2018 International Conference on Sustainable Information Engineering and Technology (SIET), 151-155.

Han, J., \& Kamber, M. (2006). Classification and prediction. Data Mining: Concepts and Techniques, 347-350.

Hasanah, U., Nurcahyo, G. W., \& Santony, J. (2018). Indikator pemilihan jurusan pada SMK Nusantara menggunakan metode SAW. Jurnal Mantik Penusa, 22(1).

Hermanto, N. (2012). Sistem pendukung keputusan menggunakan metode Simple Additive Weighting (Saw) untuk menentukan jurusan pada Smk Bakti Purwokerto. Semantik, 2(1).

Kabari, L. G., \& Nwachukwu, E. O. (2013). Decision support system using decision tree and neural networks. Computer Engineering and Intelligent Systems, 4(7), 8-19.

Kusuma, W. I. (2015). Sistem pendukung keputusan pemilihan jurusan pada Sekolah Menengah Kejuruan dengan metode Decision Tree. Prosiding Seminar Informatika Aplikatif Polinema, 186-188.

Permana, S. D. H. (2015). Sistem penunjang keputusan pemilihan sekolah menengah kejuruan teknik komputer dan jaringan yang terfavorit dengan menggunakan multi-criteria decision making. Jurnal Teknologi Informasi Dan Ilmu Komputer, 2(1), 11-19.

Rismayanti, R. (2018). Decision Tree penentuan masa studi mahasiswa Prodi Teknik Informatika (Studi kasus: Fakultas Teknik dan Komputer Universitas Harapan Medan). Query: Journal of Information Systems, 2(1).

Sahu, G., \& Khare, R. K. (2014). Decision tree classification based decision support system for derma disease. International Journal of Computer Applications, 94(17), 21-26.

Sambani, E. B., \& Nuraeni, F. (2017). Penerapan Algoritma C4. 5 untuk klasifikasi pola penjurusan di Sekolah Menengah Kejuruan (SMK) Kota Tasikmalaya. CSRID (Computer Science Research and Its Development Journal), 9(3), $149-157$.

Sulystiyawati, E. W., \& Purwaningsih, I. E. (2014). Peran hasil tes penjurusan studi terhadap pemilihan jurusan pada siswa sma. Jurnal Spirits, 5(1), 35-47. 